\title{
THE IMPACT OF THE BOLSA FAMÍLIA PROGRAM ON GDP OF MUNICIPALITIES OF THE STATE OF SERGIPE (BRAZIL): 2004-2012
}

\section{O IMPACTO DO PROGRAMA BOLSA FAMÍLIA SOBRE O PIB DOS MUNICÍPIOS DO ESTADO DE SERGIPE (BRASIL): 2004-2012}

\author{
Marco Antonio Jorge* \\ Sirley Maclaine da Graça*
}

\begin{abstract}
The objective of the present paper is to observe whether the Bolsa Familia Program (PBF), a Brazilian conditioned cash transfer program, had influence on GDP of the municipalities of the state of Sergipe during the years 2004-2012. Its innovative feature lies in the investigation of the macroeconomic impacts of PBF in the state of Sergipe. After presentation of the origins, the design and the PBF macroeconomic as well as consumption impacts, it is made a brief description of the focused region: the state of Sergipe. Employing the methodology of panel data analysis we conclude that results does not prove the PBF influence on GDP of the investigated municipalities.
\end{abstract}

Keywords: State of Sergipe (Brazil); Bolsa Família Cash Transfer Program; Local GDP.

\section{RESUMO}

O objetivo do presente artigo é observar se o Programa Bolsa Família (PBF), programa brasileiro de transferência condicionada de renda, teve influência no PIB dos municípios sergipanos durante o período 2004-2012. A contribuição do trabalho consiste na análise dos impactos macroeconômicos do PBF no estado de Sergipe. Após a apresentação das origens, do desenho do Programa, bem como de seus impactos macroeconômico e sobre o consumo, faz-se uma breve descrição da região focalizada - Sergipe. Através da metodologia de análise de dados em painel conclui-se que não há influência palpável do PBF sobre o PIB dos municípios investigados.

Palavras-Chave: Estado de Sergipe; Programa Bolsa Família (PBF); PIB Municipal.

\footnotetext{
“Doutor em Economia de Empresas pela Fundação Getúlio Vargas (SP); Professor Associado do Departamento de Economia da Universidade Federal do Sergipe (UFS).

** Mestre em Desenvolvimento Regional e Gestão de Empreendimentos Locais pela Universidade Federal do Sergipe (UFS); Professora do Departamento de Contabilidade da Universidade Federal de Sergipe (UFS).
} 


\section{INTRODUCTION}

During the first fifteen years of the 21 st century, the Brazilian government actions have been developed to eradicate and reduce poverty, whose main face is the insufficient income. According to the website of the Ministry of Social Development and Fight against Hunger (MDS), "insufficiency of income is a relevant indicator of deprivation, but is not the only one. Social, geographical and biological factors multiply or reduce the impact exerted by the yields on each individual. Among the most disadvantaged lacks education, access to land and inputs for production, health, housing, justice, family support, access to credit and opportunities (www.mds.gov.br, acessed 08.01.2013).

In this sense, the government instituted the Brazil without Misery Plan (Plano Brasil sem Miséria), which was based on three pillars: income transfer; access to public services and productive inclusion. According to the objective of the plan expressed in the same website, it is possible "to raise the per capita family income, increase access to public services, to actions of citizenship and social welfare, and increase access to employment and income opportunities through actions of productive inclusion in urban and rural areas." Actually, the plan was an expansion of the Bolsa Família Program (PBF) (www.mds.gov.br, acessed 08.01.2013).

According to Fagnani (2012, p. 6), the social policies of the Brazilian government have been recognized in the report of 26 October 2011 of the Organization for Economic Cooperation and Development (OECD), where it was stressed that "never it has seen poverty and inequality fall so fast" as in Brazil. According to the Ministry of Social Development, this was due to the Bolsa Família Program (PBF), which is one of the pillars of Brazil without Misery. The goal of the program is to reduce poverty of the Brazilian regions and, therefore, the release of funds is due to the registration of people of each region. The idea is that this release occurs in the best possible way to meet all the people in poverty and misery conditions. Thus, state and local governments must ensure that this objective is fully met and that the Bolsa Família Program bears good results according to the needs of each region (www.mds.gov.br).
So this paper starts from the assumption that the PBF has not only micro but also macroeconomic impacts and the lower the economic strength of a city, the more important must be such impacts in relative terms. In this sense, the study aims to observe the impact of the direct income PBF transfers on GDP of municipalities in the state of Sergipe between 2004 and 2012.

In order to achieve this end, the work is divided into four sections, besides this introduction: the first one presents the origins, the design and the macroeconomic impacts of PBF as well as its effects on the consumption of its beneficiaries. The second section briefly describes the focused region, while the third section presents the data and methodology employed, and analyzes the results obtained from panel data analysis, too. Finally, the main conclusions are summarized.

\section{ANALYSIS OF THE BOLSA FAMÍLIA PROGRAM}

This section presents the origins, the design, the evolution of the program's coverage in the state of Sergipe in the period 2004-2010, and report the results of research on its macroeconomic impacts and on the consumption of its beneficiaries.

\section{THE ORIGIN OF THE BOLSA FAMÍLIA}

The implementation of liberalizing policies in Latin America since the mid-1980s and the following decade was not able to promote sustained economic growth in the region and brought negative consequences such as a worsening of income distribution and social vulnerability.

Thus, the Gini index, calculated from data of individuals of working age with positive income reported in the National Survey of Sample Households (PNAD), departs from 0,584 in 1981 to 0,636 in 1989 showing an increase in the concentration of income in that decade; it oscillates slightly and reaches a new peak of 0,604 in 1993 to maintain some stability by the end of the 1990s. Nevertheless it presents a strong fall during the first fourteen years of the 21 st century.

Figure 1 shows the evolution of Brazilian Gini Index in the 1981-2014 period. 
Figure 1: Gini Index- Brazil - 1981-2014

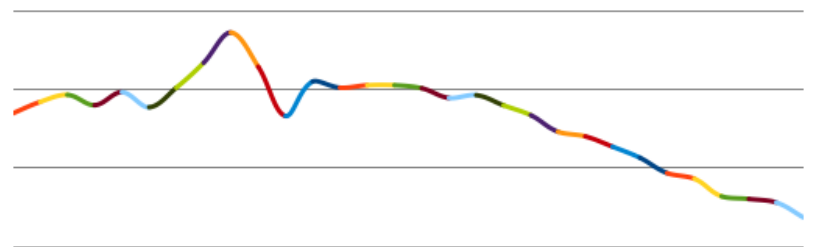

Source: www.ipeadata.gov.br (accessed 07.20.2019)

In the 1990s, a set of income transfer policies - conditional and unconditional - began to be implemented at the national level, among which the following can be mentioned: Bolsa Escola, a conditional cash transfer program to attendance at primary education, the Fome Zero and Bolsa Alimentação Programs, who sought to associate the transfer to food security, the first unconditionally and the second conditional on carrying out health and vaccination check ups; and Vale Gas, which granted subsidies to poor families to buy cooking gas (SOARES ET AL, 2010).

The Bolsa Família Program (PBF) is the integration of the four programs being set up in October 2003 and converted into Law 10.836 approved in January 2004.

According to Marques (2013), the PBF integrates the second generation of welfare programs introduced in Latin America to offset the negative consequences caused by the macroeconomic policies adopted in the region in the 1980s and 1990s, in particular the increase in the number of individuals in social vulnerability situation.

Such policies have as common features:

- Focus on poor and indigent families, especially with children and adolescents;

- Settlement of conditionalities and

- Goal of human capital accumulation by their beneficiaries in the long run.

As specific features of the Bolsa Família, in relation to other conditional cash transfer programs existing in Latin America, can be highlighted: i. selfdeclared income by households. This figure, however, is confronted by Ministry of Social Development (MDS) with consumption information contained in the Cadastro Único (Application Form). If consumption is $20 \%$ higher than the reported income, this information must be checked; ii. existence of an unconditional benefit (fixed amount) for families in extreme poverty and iii. decentralization in program management, where the inclusion of families in the Application Form is done by municipalities, as well as information updating and verification of compliance with the conditionalities. The direct deposit in the accounts of the beneficiaries and the transfer of funds to municipalities for program management are in charge of the Ministry of Social Development.

To boost the efficiency of local governments in the management of PBF, MDS created a decentralized management index, which measures the performance of municipalities in updating their records and informations related to the conditionalities. A good performance in the index ensures additional resources to the localities.

Another distinctive character of PBF is its size: according to Russel (2013), it is the largest conditional cash transfer program in the world, with coverage estimated by the author to about 41 million individuals. Nevertheless, for Marques (2013), according to data from June 2011, the PBF catered for 12.4 million families. Considering that each poor family has 4.4 members on average (Marques, 2013, p. 301 ), this implies the coverage of a contingent of 54.7 million people or $28.6 \%$ of the Brazilian population. According Andrade et al (2012) PBF encompassed about 11 million households representing about 45 million people or $25 \%$ of the country's population.

Notwithstanding the differences in estimated coverage by these authors, no one disputes the importance of the program in terms of scope. At the end of the 1st. half of 2013, the MDS website information showed that the PBF attended 11.87 million households.

\section{THE BOLSA FAMÍLIA - DESIGN IN 2013}

The PBF has its focus on families in poverty and extreme poverty situation, defined in terms of family monthly per capita income (ypc). Families with ypc $\leq \mathrm{R} \$ 70.00$ were considered in extreme poverty, while families classified as poor were those where $\mathrm{R} \$$ $70.00<$ ypc $\leq \mathrm{R} \$ 140.00$.

The monthly benefits of the program were threefold: 
- basic allowance in the fixed amount of R $\$ 70.00$ unconditional - for extremely poor families,

- variable allowance of $\mathrm{R} \$ 32.00$ per $0-15$ years old child up to the limit of three children and

- variable allowance of $\mathrm{R} \$ 38.00$ per 16-17 years old child up to the limit of two teenagers by family.

The latter are conditioned on minimum school attendance $(87 \%$ in the first case and $75 \%$ in the second), vaccination of children under seven years of age, health monitoring of 14-44 years old women as well as of nursing mothers and their babies, besides conducting pre-natal examinations in pregnant women.

So in the case of meeting conditionalities, an extremely poor family can receive a maximum benefit of $\mathrm{R} \$ 242.00$ per month, equivalent to $35.7 \%$ of the minimum wage in May 2013. If, nevertheless, family stay with ypc below $\mathrm{R} \$ 70.00$ the program transfers extra allowance until this minimum level is reached (strategy recently implemented under the Brazil Without Misery Program).

It is important to remember that the program's coverage was expanded in 2008 with the inclusion of benefit for teens.

Regarding its focus, according to Soares et al (2010), the PBF is one of the top ten among 122 existing cash transfer programs in the world. For the authors, however, there is a trade-off between efficiency in targeting and expanding coverage. In spite of this, given its magnitude, it seems that the PBF solved this dilemma satisfactorily.

Marques (2013) points to an institutional weakness, in that the PBF is not part of funding for social security so that its resources depend on the existence of budgetary allocation. In addition, "in legal terms, it may suffer disruption or even be extinguished in the case of a new president have different comprehension with respect to poverty reduction strategies" (p. 309).

The profile of conditionalities is linked to the idea of human capital accumulation by the beneficiaries. Human capital can be defined as the stock of skills and knowledge capable of providing an individual increasing their productivity and hence an additional stream of income (JORGE, 2011, p. 47). The accumulation of human capital is thus closely linked to the acquisition of education, but according to
Becker (1975) one can get human capital through work experience, training, health, nutrition, information and even through migration, as well.

By this way, targeting the provision of improvement in education, health and nutritional status of beneficiaries, the PBF seeks to elevate their stock of human capital as a tool for overcoming poverty (MARQUES, 2013). However, while the main beneficiaries are children and adolescents, the strategy for overcoming poverty is a long-term one, since that will be achieved by the next generation.

In this sense, Soares et al (2006) suggest that an income positive shock, but transitory, should not be ground for exclusion of the Program due to the high turnover of the Brazilian labor market. The argument can be added to concern over the possibility of disruption in human capital accumulation by the beneficiaries.

According to Oliveira and Sousa (2009), however, the conditioning is not always able to generate the desired results because: i. Potential beneficiaries may not want to participate in the program, even if it is well targeted and ii. monitoring compliance with the conditionalities can be costly or performed ineffectively.

In the case of PBF monitoring of school attendance is made by the schools themselves and sent to the Ministry of Social Development (MDS), while health agents and service centers are responsible for monitoring the health conditions. The monitoring of health conditionalities, which was quite poor at the beginning of the implementation of PBF (ANDRADE ET AL, 2012) improved gradually and had reached a coverage of almost $60 \%$ by the end of 2008 , according to Soares et al (2010) and $73.2 \%$ at the end of the 1 st half of 2013, according to the MDS website information.

In May 2011 the PBF was improved and integrated into the Brazil without Misery Plan. By the way, some government coordinated actions with respect to social programs were implemented. Thus, the PBF was included in the Pluri-Annual Plan (PPA) 2012/2015 aiming to "improve the socioeconomic conditions of poor and, above all, extremely poor families through direct income transfer and coordination with other policies promoting emancipation". 
Let's see how the program's coverage has evolved in the state of Sergipe.

\section{EVOLUTION OF THE BOLSA FAMÍLIA COVERAGE}

Nationally, the number of households covered goes from 6,571,839 in 2004 to 12,778,220 in 2010, or roughly doubles (growth $94.4 \%$ ), representing the addition of 6.2 million families in the period.

With regard to the state of Sergipe R\$272.6 million were paid through PBF in 2010, which puts him to 17 th position in terms of transfers among Brazilian states. With just over 230,000 families in the program, the state is ranked 17 th as well as in terms of beneficiaries.

The number of families covered by PBF in the state departs from 113,100 in 2004 to 230,400 in 2010, corresponding to the incorporation of 117,300 families in the period, that is more than double (expansion $103.64 \%$ ).

Municipalities with more families are Aracaju, Nossa Senhora do Socorro, Lagarto, Itabaiana and São Cristóvão, with respectively 34,747, 19,037, 11,568, 9,780 and 8,074 families. Aracaju, Nossa Senhora do Socorro, Itabaiana and São Cristóvão are also among the municipalities that have incorporated more beneficiaries in the period, along with the city of Estancia.

Due to the small size of most municipalities in Sergipe, nineteen of them had less than 1,000 families covered by the program in 2010 .

Regarding the amount of resources paid through PBF, the volume of funds transferred almost quadrupled in the period (expansion 297.5\%), from R\$ 68.6 million in 2004 to R\$ 272.6 million in 2010.

During this last year, the localities that received the highest value were Aracaju, Nossa Senhora do Socorro, Lagarto, Itabaiana and São Cristóvão, whose amount received through the PBF was, respectively, $\mathrm{R} \$ 35.6 ; \mathrm{R} \$ 21.3 ; \mathrm{R} \$ 14.7 ; \mathrm{R}$ \$ 10.6 and $\mathrm{R} \$ 9.9$ million. While the first four municipalities received more than $\mathrm{R} \$ 10$ million in 2010, fourteen locations in turn, received under R\$ 1 million in that year, according to data from the MDS website.

In this sense, the PBF is a program aimed to combat poverty increasing acquisition of human capital of their beneficiaries, but the interactions of these individuals, combined with the volume of funds transferred by the program end up generating a positive externality to boost the local economy and thus contribute to the growth of municipalities, especially the smallest.

\section{EFFECTS OF THE BOLSA FAMÍLIA PROGRAM}

Cash transfer programs have macroeconomic effects, as well as microeconomic effects on beneficiaries. The latter are particularly affected by the content of conditionality. In this section the macroeconomic effects of PBF will be focused, as well as the effects on consumption of beneficiary families.

\section{MACOECONOMIC EFFECTS:}

Low-income families often have high marginal propensity to consume. Thus, it is expected that cash transfers received by PBF beneficiaries are spent on consumer goods, particularly non-durable goods such as food or clothing. The expenditure of this resource, by the way promotes the local economy, with significant multiplier effect mainly in low-income municipalities (MARQUES, 2013).

Both public and private spending has a multiplier effect on additional income. There is a multiplier effect because every increase in income generates an increase in consumption, which in turn increases income again, making the final increase larger than the initial increase caused by greater government spending and creating a cyclical process of increasing income and consumption.

Thus, MDS (2011, p. 144), citing a study of the Brazilian Institute of Applied Economics (IPEA) states that "spending on the PBF is characterized as the largest multiplier effect on the income of families (every R\$ 1.00 spent results in $\mathrm{R} \$ 1.82$ impact on income), and one of the largest multiplier effect on GDP (every R\$ 1.00 spent results in R 1.44 impact on GDP)."

Yet about the macroeconomic effects, Campelo and Neri (2013) argue that income transfers that favor the poorest households have the highest multiplier effects and commented that, among these, the PBF has the best multiplier effect: they estimate that every 
$\mathrm{R} \$$ added spent in PBF stimulate a growth of $\mathrm{R} \$$ 1.78 in GDP. Thus the Bolsa Familia Program plays an important role in the Brazilian macroeconomic dynamics, especially in the small municipalities whose economy is very dependent on such transfers.

\section{CONSUMPTION:}

At the microeconomic level, Oliveira e Sousa (2009) estimated the impact of PBF on total consumption of the beneficiaries, as well as its composition. The results are shown in the table below:

Table 1 PBF Effects on the Consumption -

Beneficiaries x Control Group II - Brazil (R \$ annual amount)

\begin{tabular}{l|l|l}
\hline VARIÁBLE & POOR & EXTREMELY POOR \\
\hline Total Consumption & - & $\mathrm{R} \$ 458.65$ \\
\hline Food Expenditures & $\mathrm{R} \$ 278.12$ & $\mathrm{R} \$ 388.22$ \\
\hline Education Expenditures & $\mathrm{R} \$ 31.80$ & - \\
\hline $\begin{array}{l}\text { Children's Apparel } \\
\text { Expenditures }\end{array}$ & $\mathrm{R} \$ 16.12$ & $\mathrm{R} \$ 31.94$ \\
\hline
\end{tabular}

(-) not significant

Source: Oliveira e Sousa (2009).

Table 1 shows the annual difference in expenditures between the PBF beneficiary families and low-income families not covered by income transfer programs. Since the values are positive, it can be seen that poor households spent more on food, education and children's apparel as compared to the control group. Families in extreme poverty beneficiaries of PBF in turn spent even more in terms of total consumption, expenditures on food and children's clothing.

To Oliveira e Sousa (2009), this result is interesting, because the allowance received as cash transfer could not result in an immediate increase in consumption, given that beneficiaries could use the money to pay off debts or to undertake a business.

Soares et al (2010) attribute this result to the likely perception on the part of beneficiary families, that the transfer should be used in the interests of their children. The fact that the benefit is delivered to mothers certainly contributes to this perception.

\section{THE STATE OF SERGIPE}

Sergipe is the smallest state in Brazil and is located in the Northeast Region. Map 1 shows that it has an area of $21,910.3 \mathrm{~km} 2$, representing only $0.3 \%$ of the country and $1.4 \%$ of the Northeast areas.

Sergipe is limited to the north with the state of Alagoas through the São Francisco River which separates both states, to the west and south borders on Bahia and to east, with the Atlantic Ocean.

In 2010 the state had 2,068,017 inhabitants and its population density was 94.3 people per square kilometer; in the first decade of the 21 st century the population growth was $1.5 \%$ per year. The total population of Sergipe corresponds to $1.1 \%$ of the Brazilian population according to the Brazilian Institute of Geography and Statistics (IBGE).

Map 1 - Limits and Extreme Points - Sergipe

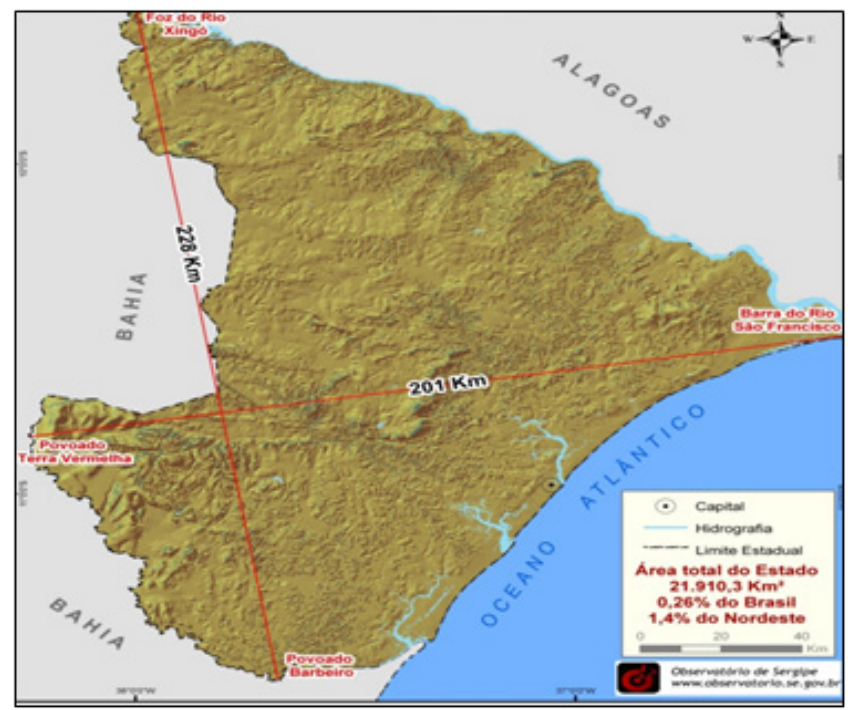

Source: SUPES/SEPLAG (2014)

Its gross domestic product was $\mathrm{R} \$ 23.9$ billion; which corresponds to a GDP per capita equivalent to $\mathrm{R} \$ 11,572.44$ (IBGE, 2010). The service sector accounts for $59.7 \%$ of GDP, as the industrial and agricultural sectors account respectively for $25.5 \%$ and $4.1 \%$ of GDP. Taxes on product net of subsidies amounted to $10.7 \%$.

Municipalities in the state are in general small: only two of them, Aracaju - the capital - and Nossa Senhora do Socorro had more than 100,000 
inhabitants ${ }^{1}$. The vast majority ( $68 \%$ or 51 cities) had fewer than 20,000 inhabitants.

The same occurs with regard to the economic size of these locations: only four cities have a GDP of more than R\$ 1 billion, while the economy of about half, 38 municipalities or $50.7 \%$, reached less than $\mathrm{R} \$$ 100 million in 2010. In localities of fragile economies, such as these reported, it is likely that cash transfer programs have a more significant economic impact, as demonstrated by Jorge e Graça (2014), which makes the state of Sergipe appropriate to carry out this study, despite of its small size.

The size and reduced economy ends up to be reflected in the level of development of these municipalities: with regard to Human Development Index (IDH-M), most cities of Sergipe (43 or 57.3\%) were classified in the low human development category and only the capital, Aracaju, reaches the high human development category.

In 2007, the state government created eight planning areas in order to regionalize investment decisions, increase participation of society in the decision-making process and thus attack three concentrations existing in the state: the concentration of income and production structure in its coastal strip which at that time accounted for $70 \%$ of value added, and industrial concentration around the Petrobras and CHESF which accounted for nearly $40 \%$ of Sergipe industrial GDP. (TEIXEIRA ET AL, 2010).
Map 2 shows the distribution of Sergipe planning territories: Baixo São Francisco (14 municipalities); Alto Sertão (07 municipalities); Agreste (15 municipalities); Centro Sul (05 municipalities); Grande Aracaju (09 municipalities); Leste Sergipano (09 municipalities); Médio Sertão (06 municipalities) and Sul Sergipano (11 municipalities).

Table 2 confronts the amounts transferred by the PBF with municipal GDP's and calculates their impact on the local economy, considering a multiplier effect of 1.8:

Map 2 -Planning Areas - Sergipe

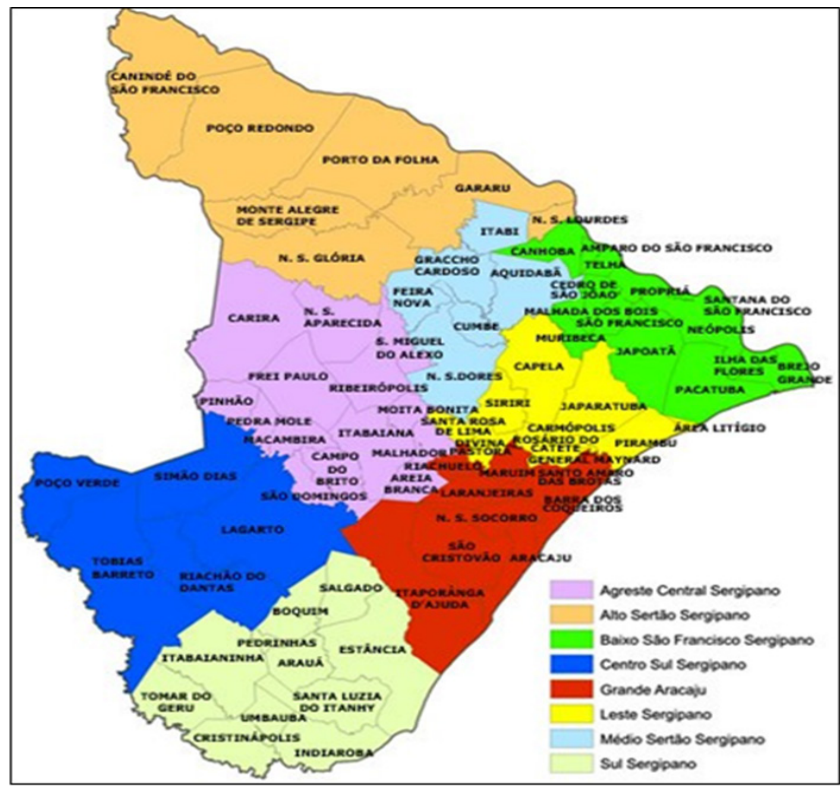

Source: SUPES/SEPLAG (2014)

Table 2: Bolsa Família Resources and Impacts on GDP - With and without Multiplier Effect - 2012 (R\$)

\begin{tabular}{l|l|l|l|l|l}
\hline MUNICIPALITY & $\begin{array}{l}\text { PBF Value } \\
\text { Transferred }\end{array}$ & $\begin{array}{l}\text { Value considering } \\
\text { Multiplier Effect }\end{array}$ & GDP & \% of GDP & $\begin{array}{l}\text { \% of GDP considering } \\
\text { Multiplier Effect }\end{array}$ \\
\hline Amparo de São Francisco & 561,042 & $1,077,201$ & $18,469,054$ & 3.04 & 5.83 \\
\hline Aquidabã & $4,298,766$ & $8,253,631$ & $142,671,105$ & 3.01 & 5.79 \\
\hline Aracaju & $51,262,718$ & $98,424,419$ & $9,813,851,609$ & 0.52 & 1.00 \\
\hline Arauá & $2,960,500$ & $5,684,160$ & $70,589,138$ & 4.19 & 8.05 \\
\hline Areia Branca & $3,804,280$ & $7,304,218$ & $130,047,550$ & 2.93 & 5.62 \\
\hline Barra dos Coqueiros & $4,448,168$ & $8,540,483$ & $333,515,485$ & 1.33 & 2.56 \\
\hline Boquim & $6,253,668$ & $12,007,043$ & $294,652,052$ & 2.12 & 4.07 \\
\hline Brejo Grande & $2,023,086$ & $3,884,325$ & $57,110,660$ & 3.54 & 6.80 \\
\hline Campo do Brito & $3,723,346$ & $7,148,824$ & $116,939,272$ & 3.18 & 6.11 \\
\end{tabular}


continuação

\begin{tabular}{|c|c|c|c|c|c|}
\hline MUNICIPALITY & $\begin{array}{l}\text { PBF Value } \\
\text { Transferred }\end{array}$ & $\begin{array}{l}\text { Value considering } \\
\text { Multiplier Effect }\end{array}$ & GDP & $\%$ of GDP & $\begin{array}{l}\text { \% of GDP considering } \\
\text { Multiplier Effect }\end{array}$ \\
\hline Canhoba & $1,183,866$ & $2,273,023$ & $30,208,789$ & 3.92 & 7.52 \\
\hline Canindé de São Francisco & $7,030,250$ & $13,498,080$ & $1,399,830,529$ & 0.50 & 0.96 \\
\hline Capela & $6,932,392$ & $13,310,193$ & $267,146,001$ & 2.59 & 4.98 \\
\hline Carira & $5,161,030$ & $9,909,178$ & $147,503,367$ & 3.50 & 6.72 \\
\hline Carmopolis & $2,811,364$ & $5,397,819$ & $620,406,715$ & 0.45 & 0.87 \\
\hline Cedro de São João & $1,334,006$ & $2,561,292$ & $35,242,691$ & 3.79 & 7.27 \\
\hline Cristinapólis & $4,449,804$ & $8,543,624$ & $109,120,486$ & 4.08 & 7.83 \\
\hline Cumbe & 919,222 & $1,764,906$ & $29,635,909$ & 3.10 & 5.96 \\
\hline Divina Pastora & $1,064,288$ & $2,043,433$ & $211,624,004$ & 0.50 & 0.97 \\
\hline Estancia & $11,753,018$ & $22,565,795$ & $1,303,712,678$ & 0.90 & 1.73 \\
\hline Feira Nova & $1,576,476$ & $3,026,834$ & $42,331,158$ & 3.72 & 7.15 \\
\hline Frei Paulo & $2,733,050$ & $5,247,456$ & $194,721,792$ & 1.40 & 2.69 \\
\hline Gararu & $3,539,840$ & $6,796,493$ & $80,742,712$ & 4.38 & 8.42 \\
\hline General Maynard & 538,698 & $1,034,300$ & 19125183 & 2.82 & 5.41 \\
\hline Graccho Cardoso & $1,778,172$ & $3,414,090$ & $41,017,621$ & 4.34 & 8.32 \\
\hline Ilha das Flores & $2,401,196$ & $4,610,296$ & $47,602,808$ & 5.04 & 9.68 \\
\hline Indiaroba & $4,405,614$ & $8,458,779$ & $99,512,977$ & 4.43 & 8.50 \\
\hline Itabaiana & $15,176,728$ & $29,139,318$ & $1,005,866,162$ & 1.51 & 2.90 \\
\hline Itabaianinha & $10,610,630$ & $20,372,410$ & $250,449,941$ & 4.24 & 8.13 \\
\hline Itabi & $1,220,116$ & $2,342,623$ & $38,640,205$ & 3.16 & 6.06 \\
\hline Itaporanga d' Ajuda & $7,463,138$ & $14,329,225$ & $600,482,748$ & 1.24 & 2.39 \\
\hline Japaratuba & $3,715,506$ & $7,133,772$ & $619,527,282$ & 0.60 & 1.15 \\
\hline Japoatã & $3,653,742$ & $7,015,185$ & $101,034,831$ & 3.62 & 6.94 \\
\hline Lagarto & $20,004,342$ & $38,408,337$ & $865,259,485$ & 2.31 & 4.44 \\
\hline Laranjeiras & $5,872,642$ & $11,275,473$ & $1,010,389,032$ & 0.58 & 1.12 \\
\hline Macambira & $1,565,544$ & $3,005,844$ & $43,968,696$ & 3.56 & 6.84 \\
\hline Malhada dos Bois & 881,498 & $1,692,476$ & $30,111,370$ & 2.93 & 5.62 \\
\hline Malhador & $2,727,370$ & $5,236,550$ & $76,136,590$ & 3.58 & 6.88 \\
\hline Maruim & $3,541,006$ & $6,798,732$ & $204,414,352$ & 1.73 & 3.33 \\
\hline Moita Bonita & $1,982,790$ & $3,806,957$ & $71,659,907$ & 2.77 & 5.31 \\
\hline Monte Alegre de Sergipe & $3,631,166$ & $6,971,839$ & $92,774,961$ & 3.91 & 7.51 \\
\hline Muribeca & $1,658,322$ & $3,183,978$ & $58,514,814$ & 2.83 & 5.44 \\
\hline Neopolis & $5,022,692$ & $9,643,569$ & $165,026,628$ & 3.04 & 5.84 \\
\hline Nossa Senhora Aparecida & $2,334,842$ & $4,482,897$ & $80,459,176$ & 2.90 & 5.57 \\
\hline Nossa Senhora da Gloria & $7,911,258$ & $15,189,615$ & $346,380,842$ & 2.28 & 4.39 \\
\hline Nossa Senhora das Dores & $5,727,240$ & $10.996,301$ & $217,584,931$ & 2.63 & 5.05 \\
\hline Nossa Senhora de Lourdes & $1,642,434$ & $3,153,473$ & $42,042,523$ & 3.91 & 7.50 \\
\hline Nossa Senhora do Socorro & $29,316,702$ & $56,288,068$ & $2,049,719,308$ & 1.43 & 2.75 \\
\hline Pacatuba & $4,191,824$ & $8,048,302$ & $111,861,631$ & 3.75 & 7.19 \\
\hline Pedra Mole & 724,434 & $1,390,913$ & $21,850,498$ & 3.32 & 6.37 \\
\hline Pedrinhas & $2,311,250$ & $4,437,600$ & $50,293,335$ & 4.60 & 8.82 \\
\hline Pinhão & $1,386,874$ & $2,662,798$ & $41,139,348$ & 3.37 & 6.47 \\
\hline Pirambu & $1,964,252$ & $3,771,364$ & $69,584,609$ & 2.82 & 5.42 \\
\hline
\end{tabular}


conclusão

\begin{tabular}{|c|c|c|c|c|c|}
\hline MUNICIPALITY & $\begin{array}{l}\text { PBF Value } \\
\text { Transferred }\end{array}$ & $\begin{array}{l}\text { Value considering } \\
\text { Multiplier Effect }\end{array}$ & GDP & $\%$ of GDP & $\begin{array}{l}\text { \% of GDP considering } \\
\text { Multiplier Effect }\end{array}$ \\
\hline Poço Redondo & $9,009,224$ & $17,297,710$ & $187,705,974$ & 4.80 & 9.22 \\
\hline Poço Verde & $6,007,542$ & $11,534,481$ & $133,678,448$ & 4.49 & 8.63 \\
\hline Porto da Folha & $7,619,018$ & $14,628,515$ & $197,471,551$ & 3.86 & 7.41 \\
\hline Propria & $5,909,202$ & $11,345,668$ & $313,990,016$ & 1.88 & 3.61 \\
\hline Riachão do Dantas & $5,488,382$ & $10,537,693$ & $113,901,537$ & 4.82 & 9.25 \\
\hline Riachuelo & $2,246,118$ & $4,312,547$ & $148,608,454$ & 1.51 & 2.90 \\
\hline Ribeiropólis & $3,571,660$ & $6,857,587$ & $152,027,072$ & 2.35 & 4.51 \\
\hline Rosário do Catete & $2,087,730$ & $4,008,442$ & $408,965,323$ & 0.51 & 0.98 \\
\hline Salgado & $4,194,778$ & $8,053,974$ & $118,824,982$ & 3.53 & 6.78 \\
\hline Santa Luzia do Itanhy & $4,293,272$ & $8,243,082$ & $101,227,623$ & 4.24 & 8.14 \\
\hline Santa Rosa de Lima & $1,046,768$ & $2,009,795$ & $26,201,708$ & 4.00 & 7.67 \\
\hline Santana do São Francisco & $2,031,343$ & $3,900,179$ & $41,939,351$ & 4.84 & 9.30 \\
\hline Santo Amaro das Brotas & $2,641,976$ & $5,072,594$ & $107,527,486$ & 2.46 & 4.72 \\
\hline São Cristovão & $14,469,674$ & $27,781,774$ & $590,068,921$ & 2.45 & 4.71 \\
\hline São Domingos & $2,548,782$ & $4,893,661$ & $66,069,671$ & 3.86 & 7.41 \\
\hline São Francisco & 807,888 & $1,551,145$ & $23,585,720$ & 3.43 & 6.58 \\
\hline São Miguel do Aleixo & $1,083,802$ & $2,080,900$ & $27,030,731$ & 4.01 & 7.70 \\
\hline Simão Dias & $9,741,316$ & $18,703,327$ & $374,946,437$ & 2.60 & 4.99 \\
\hline Siriri & $2,102,580$ & $4,036,954$ & $162,853,112$ & 1.29 & 2.48 \\
\hline Telha & 792,656 & $1,521,900$ & $21,369,704$ & 3.71 & 7.12 \\
\hline Tobias Barreto & $11,010,288$ & $21,139,753$ & $337,076,507$ & 3.27 & 6.27 \\
\hline Tomar do Geru & $3,836,358$ & $7,365,807$ & $77,866,561$ & 4.93 & 9.46 \\
\hline Umbaúba & $5,249,006$ & $10,078,092$ & $167,750,043$ & 3.13 & 6.01 \\
\hline
\end{tabular}

Source: www.mds.gov.br and www.seplag.se.gov.br (accessed 06.10.2013)

The fourth column of the table shows the direct impact of the value transferred by PBF as a proportion of municipal GDP in 2012. Note that the PBF transfers account for $0.45 \%$ to $5.04 \%$ of the local product; with the lowest impact just occurring in Carmópolis, city of great economic dynamism, and the greatest impact occurring in the municipality of Ilha das Flores.

Based on the multiplier effect of the program estimates referred to in section 2.4.1,- around 1.8 - it tried out to estimate the direct and indirect impact of PBF in each municipality. This impact is expressed in absolute value in column 2, and as a percentage of GDP in the last column of the table. When considering the multiplier effect, the PBF impact shall range from $0.87 \%$ to $9.68 \%$ of GDP.

So, it seems that the resources transferred under PBF have a non-negligible impact on the local economy. It is now necessary to verify the validity of this hypothesis through an estimate of greater consistency, which is done in the next section.

\section{MODEL DESCRIPTION AND ANALYSIS OF RESULTS}

This section briefly describes the data panel analysis technique as well as the model estimated and its results. Finally, it presents the analysis of the latter.

\section{DESCRIPTION OF THE TECHNIQUE}

In this work will be used panel data analysis technique, which is the combination of cross-sectional analysis with the time series. Among the advantages of this technique we can enumerate the increased number of degrees of freedom from $(\mathrm{N}-\mathrm{k})$ to $(\mathrm{NT}$ $\mathrm{k})$, increased robustness of the tests $\mathrm{t}$ and $\mathrm{F}$, as well as more efficient estimators.

Despite its neighborhood and sharing many common features as small size and little substantial economies, each municipality of the analyzed region has its specificities and some of them, such as social 
capital, for example, may have some influence on GDP, or even on the efficient operation of the PBF, without being directly observed. Thus, the fixed effects technique assumes that these unobserved variables are correlated with the explanatory variables in the model.

The technique of random effects, on the other hand, requires strict exogeneity, that is, the absence of correlation between the explanatory variables and the idiosyncratic error as well as absence of correlation also with the unobserved variables.

If the results of the fixed effects estimates and random-effects differ, it is necessary to choose which technique is most appropriate. Instruments available for such judgment are Hausman or Sargan-Hansen specification tests which consist in comparing the estimates of fixed effect and random effect, testing the hypothesis of independence between the unobserved variable, which is assumed to be variable in time, and explanatory variables. In the case of a significant difference between the estimates, it rejects the hypothesis of independence, which is a technical assumption of random effects (Wooldridge, 2002, p. 288-291). In this case, the fixed effects technique is considered more suitable.

In the case of small samples using fixed effects estimation, errors tend to be negatively correlated ${ }^{2}$, which makes indispensable a correction provided by the robust variance matrix.

\section{DESCRIPTION OF THE MODEL}

The basic model was built in order to determine which variables have impact on GDP of cities in the state of Sergipe. Given the importance of income transfers to the small towns, they were included as independent variables: values passed on the Bolsa Família Program - focus of this analysis - value of social security benefits (pensions and retirements) and transfers from the Fundo de Participação dos Municípios (FPM). Considering that all cities of Sergipe receive oil royalties, this information was also included among the explanatory variables. Finally, to capture the dynamics of local economies, the value added of the three economic sectors: agriculture, industry and services were included. In addition, the

\footnotetext{
${ }^{2}$ The proof will not be presented here, but a very didactic one can be found in Wooldridge (2002, p. 270).
}

amount of tax on transactions regarding the circulation of goods and services (ICMS) transferred to each municipality has been included to reflect the strength of the local economy. Although it is constituted as a transfer, it is directly related to the municipal economic dynamism, given the principle of derivation ${ }^{3}$.

Based on the above, the following equation will be estimated:

$\operatorname{GDP}_{\mathrm{i}, \mathrm{t}}=\beta_{0}+\beta_{1}$ VAAgr $_{\mathrm{i}, \mathrm{t}}+\beta_{2}$ VAInf $_{\mathrm{i}, \mathrm{t}}+\beta_{3}$ VAServ $_{\mathrm{i}, \mathrm{t}}+\beta_{4} \mathrm{FPM}_{\mathrm{i}, \mathrm{t}}+$ $\beta_{5}$ ICMS $_{i, t}+\beta_{6}$ Roy $_{i, t}+\beta_{7}$ PBF $_{i, t}+\beta_{8}$ SST $_{i, t}+\varepsilon_{i, t}$

It was attempted to avoid the analysis of a single year to minimize problems arising from exceptional situations that could bias the results. So we opted for the analysis of the first eight years available. Remembering that PBF started in 2004, the analysis period comprehends the years 2004-2012.

Information about the GDP and the value added of agriculture, industry and services are provided by State Secretary of Planning and Public Administration (SEPLAG/SE) under the Regional Accounts project which calculates the GDP's state together with the IBGE. Data are expressed in thousand R\$.

The FPM transfers and the amount received of royalties were obtained from the National Treasury website and are expressed in R\$.

The transfers of ICMS, in turn, were provided by the state Secretary of Finance (SEFAZ/SE), while the value of social security benefits was granted by the Ministry of Social Security. Both informations are expressed in R\$.

The amount of allowances paid through PBF, in turn, was obtained from the state unit of MDS. All data are expressed in current values. For estimation purposes, the original information was standardized ${ }^{4}$ in order to to improve the comparability of variables.

The assumptions of multiple regression model were tested in a pooled model using software SPSS 13.0, but were not included in the work for size reasons. The results were the following: strong occurrence of multicollinearity, which led to the withdrawal of three model variables - value added of services sector, transfers from Fundo de Participação

\footnotetext{
${ }^{3}$ The principle of derivation consists of preserving, in the resources distribution, the original location of the taxable event. In Sergipe, $75 \%$ of the ICMS amount transferred to municipalities should obey the principle of derivation (SILVA, 2013).

${ }^{4}$ The standardization was made in the conventional way by subtracting the mean and dividing each variable by standard error of the sample.
} 
dos Municípios (FPM) and transfers from the state tax on Goods and Services (ICMS). The model with the remaining variables showed low VIF's (between 1.4 and 5.1), absence of residuals autocorrelation according to the Durbin-Watson test - and the presence of heteroscedasticity as the results of White' Test. Thus, after these changes the equation 2 will be estimated:

$\mathrm{GDP}_{\mathrm{i}, \mathrm{t}}=\beta_{0}+\beta_{1}$ VAAgr $_{\mathrm{i}, \mathrm{t}}+\beta_{2}$ VAInf $_{\mathrm{i}, \mathrm{t}}+\beta_{3}$ Roy $_{\mathrm{i}, \mathrm{t}}+\beta_{4} \mathrm{SST}_{\mathrm{i}, \mathrm{t}}+$ $\beta_{5} \mathrm{PBF}_{\mathrm{i}, \mathrm{t}}+\varepsilon_{\mathrm{i}, \mathrm{t}}$

So, panel data analysis was performed using software STATA 12.0 as well as the robust variance matrix due to the heteroscedasticity detected.

\section{ANALYSIS OF RESULTS}

Table 3 presents the information concerning the dependent and independent variables, as well as their means and standard deviations. For reasons of size only the data for the year 2012 were presented.

Only six cities have a GDP of more than R\$ 1 billion, while the economy of about half, 32 municipalities or $42.7 \%$, reached less than $\mathrm{R} \$ 100$ million in 2012. Na media, o PIB está em torno de R\$ 371.0 milhões.

Agriculture accounts for about R\$ 13.8 million (3.7\% of GDP) on average, ranging from $\mathrm{R} \$ 1.2$ million in Amparo do São Francisco to R\$ 66.0 million in the municipality of Simão Dias.

The industrial sector, in turn, contributes $\mathrm{R} \$$ 94.5 million (25.5\% of GDP) on average, ranging from R\$ 1.7 million in the municipality of Pedra Mole to $\mathrm{R} \$ 1.5$ billion in the capital Aracaju.

The sector of the economy that most contributes to the GDP of most of the state's municipalities is the services sector, representing R $\$ 218.8$ million $(59.0 \%$ of GDP) on average and showing great variation: R\$ 14.3 million in Amparo do São Francisco at R\$ 6.8 billion in Aracaju.

ICMS transfers represented more than R\$ 10 million in only eight cities, which are the most dynamic in the state.

Royalties revenues are the lowest, although they also exceed R\$ 10 million in five cities (Aracaju, Canindé do São Francisco, Carmópolis, Japaratuba and Pirambu).
Social security benefit payments are, in general, the most important transfers, representing on average R\$ 24.5 million or $6.6 \%$ of municipal GDP in 2012 and contributing over $\mathrm{R} \$ 50.0$ million to the economy of five locations.

Regarding transfers from the Municipal Participation Fund (FPM) - the analysis of the PBF has already been done - these totaled about R $\$ 13.5$ million (3.6\% of GDP) in the year. Although less representative than social security contributions in value, such transfers are the most important for the finances of sparsely populated municipalities, ranging from R\$ 4.9 million in Ilha dasFlores to R\$ 196.1 million in Aracaju.

With the exception of agricultural value added, all other variables are widely dispersed, as can be seen from the comparison between the mean and standard deviation, demonstrating the relevance of data standardization to improve their comparability in terms of magnitude 5 .

Finally, an important issue concerns the possible endogeneity between Bolsa Família Program disbursements and GDP, as both are theoretically related to income. Thus, a low income would increase the number of PBF beneficiary families and reduce GDP.

In our view the issue is softened at the municipal level due to income leakages that end up making GDP different from income at the local level. Such leakages occur in small municipalities (mostly in the state of Sergipe), where many individuals work in other locations, commuting daily and returning to their homes for the night only. Even municipalities with a significant GDP, such as Canindé do São Francisco, for example, face significant income leakages due to their economic structure: the Xingó Hydroelectric Power Plant accounts for a significant fraction of GDP, but generates few jobs and income in the region despite energy royalties received.

Even so, our results should be viewed with some caution due to the possibility of endogeneity.

Table 4 shows the results of the estimates of fixed and random effects, performed in Stata 12.0, using the robust variance matrix due to the heteroscedasticity.

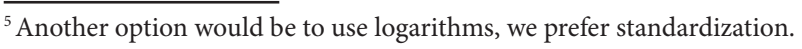


Table 3: Model Variables - Descriptive Statistics - 2012 (R\$ thousand)

\begin{tabular}{|c|c|c|c|c|c|c|c|c|c|}
\hline \multirow{2}{*}{ MUNICIPALITIES } & \multirow{2}{*}{ GDP } & \multicolumn{3}{|c|}{ VALUE ADDED } & \multirow{2}{*}{$\begin{array}{c}\text { ICMS } \\
\text { Transfers }\end{array}$} & \multirow{2}{*}{ Royalties } & \multirow{2}{*}{$\begin{array}{c}\text { Social } \\
\text { Security }\end{array}$} & \multirow{2}{*}{ PBF } & \multirow{2}{*}{ FPM } \\
\hline & & Agriculture & Industry & Services & & & & & \\
\hline Amparo de São Francisco & $18,469.05$ & $1,230.33$ & $2,235.96$ & $14,328.3$ & $2,042.63$ & 202.81 & 309.36 & 561.04 & $5,820.51$ \\
\hline Aquidabã & $142,671.11$ & $19,348.61$ & $11,948.87$ & $104,183.22$ & $2,726.67$ & $3,370.94$ & $25,998.52$ & $4,298.77$ & $11,650.38$ \\
\hline Aracaju & $9,813,851.61$ & $5,976.29$ & , 482,584.42 & i,869,736.92 & $159,786.52$ & $35,079.40$ & $706,467.30$ & $51,262.72$ & $196,146.34$ \\
\hline Arauá & $70,589.14$ & $10,047.03$ & $5,929.92$ & $51,427.01$ & $2,171.47$ & $1,368.75$ & $7,751.17$ & $2,960.50$ & $7,511.55$ \\
\hline Areia Branca & $130,047.55$ & $23,533.12$ & $12,417.57$ & $88,082.13$ & $2,552.51$ & 309.62 & $9,560.85$ & $3,804.28$ & $11,650.38$ \\
\hline Barra dos Coqueiros & $333,515.49$ & $3,764.82$ & $139,646.27$ & $166,363.46$ & $5,048.66$ & $3,611.32$ & $5,241.21$ & $4,448.17$ & $13,592.12$ \\
\hline Boquim & $294,652.05$ & $6,836.71$ & $83,356.05$ & $168,465.26$ & $3,190.54$ & 285.52 & $26,511.53$ & $6,253.67$ & $13,592.12$ \\
\hline Brejo Grande & $57,110.66$ & $7,349.09$ & $13,408.01$ & $34,941.04$ & $2,088.10$ & 284.70 & $2,417.63$ & $2,023.09$ & $5,825.19$ \\
\hline Campo do Brito & $116,939.27$ & $7,578.06$ & $16,406.24$ & $87,233.20$ & $2,488.40$ & 316.84 & $19,741.66$ & $3,723.35$ & $9,708.65$ \\
\hline Canhoba & $30,208.79$ & $5,400.75$ & $2,843.52$ & $20,938.89$ & $1,988.16$ & 85.71 & $3,748.71$ & $1,183.87$ & $5,825.19$ \\
\hline Canindé de São Francisco & $1,399,830.53$ & $24,720.01$ & , 181,625.19 & $179,281.47$ & $64,904.05$ & $12,042.45$ & $22,734.30$ & $7,030.25$ & $13,592.12$ \\
\hline Capela & $267,146.00$ & $38,836.31$ & $44,915.40$ & $168,571.82$ & $16,963.20$ & $4,015.82$ & $21,285.35$ & $6,932.39$ & $15,487.83$ \\
\hline Carira & $147,503.37$ & $16,589.29$ & $15,515.45$ & $106,780.28$ & $3,117.55$ & 253.78 & $22,440.03$ & $5,161.03$ & $11,650.38$ \\
\hline Carmopolis & $620,406.72$ & $3,155.45$ & $467,019.88$ & $118,645.57$ & $8,488.10$ & $43,997.74$ & $5,815.51$ & $2,811.36$ & $9,708.65$ \\
\hline Cedro de São João & $35,242.69$ & $3,083.74$ & $3,052.75$ & $27,792.75$ & $2,054.60$ & 149.06 & $1,460.86$ & $1,334.01$ & $5,825.19$ \\
\hline Cristinapólis & $109,120.49$ & $8,747.16$ & $11,904.65$ & $82,916.69$ & $3,742.87$ & 218.88 & $8,204.99$ & $4,449.80$ & $9,708.65$ \\
\hline Cumbe & $29,635.91$ & $6,169.11$ & $2,216.23$ & $20,310.11$ & $1,974.28$ & 150.04 & 958.07 & 919.22 & $5,825.19$ \\
\hline Divina Pastora & $211,624.00$ & $2,604.01$ & $178,958.08$ & $27,313.88$ & $2,512.58$ & $6,477.59$ & 851.60 & $1,064.29$ & $5,825.19$ \\
\hline Estancia & $1,303,712.68$ & $29,640.86$ & $484,132.6$ & $528,248.25$ & $26,679.50$ & $4,557.11$ & $72,430.09$ & $11,753.02$ & $23,300.77$ \\
\hline Feira Nova & $42,331.16$ & $9,639.94$ & $3,025.96$ & $28,165.79$ & $2,007.41$ & 168.57 & 837.26 & $1,576.48$ & $5,825.19$ \\
\hline Frei Paulo & 1.79 & $17,283.24$ & $53,842.31$ & $96,515.27$ & $5,734.12$ & 233.16 & $15,747.69$ & $2,733.05$ & $9,708.65$ \\
\hline Gararu & $80,742.71$ & $17,701.61$ & $6,301.65$ & $54,207.12$ & $2,049.68$ & 180.80 & $9,194.90$ & $3,539.84$ & $7,766.92$ \\
\hline General Maynard & $19,125.18$ & 596.59 & $3,063.09$ & $14,943.47$ & $1,970.98$ & 296.83 & 193.07 & 538.70 & $5,825.20$ \\
\hline Graccho Cardoso & $41,017.62$ & $8,811.96$ & $3,673.13$ & $27,165.08$ & $1,990.31$ & 149.06 & $1,659.01$ & $1,778.17$ & $5,825.26$ \\
\hline Ilha das Flores & $47,602.81$ & $4,893.37$ & $4,357.25$ & $36,938.18$ & $2,135.75$ & 106.76 & $3,830.60$ & $2,401.20$ & $4,893.76$ \\
\hline Indiaroba & $99,512.98$ & $15,194.03$ & $8,500.41$ & $71,305.30$ & $2,183.11$ & 249.48 & $2,912.18$ & ,405.61 & $9,708.65$ \\
\hline Itabaiana & $1,005,866.16$ & $36,463.38$ & $96,430.32$ & $742,349.29$ & $11,528.17$ & 642.21 & $87,358.11$ & $15,176.73$ & $27,184.23$ \\
\hline Itabaianinha & $250,449.94$ & $14,407.46$ & $30,958.93$ & $189,988.13$ & $3,324.68$ & 341.85 & $32,715.83$ & $10,610.63$ & $17,475.58$ \\
\hline Itabi & $38,640.21$ & $6,654.42$ & $4,088.3$ & $26,224.32$ & $2,066.09$ & 223.21 & $5,797.37$ & $1,220.12$ & $5,825.19$ \\
\hline Itaporanga d' Ajuda & $600,482.75$ & $25,165.96$ & $279,772.16$ & $211,227.36$ & $9,192.37$ & $5,452.20$ & $16,220.46$ & $7,463.14$ & $15,533.85$ \\
\hline Japaratuba & $619,527.28$ & $29,323.22$ & $470,725.46$ & $108,197.99$ & $7,349.57$ & $15,023.65$ & $14,679.94$ & $3,715.51$ & $11,650.38$ \\
\hline Japoatã & $101,034.83$ & $22,598.1$ & $9,643.60$ & $63,916.38$ & $3,166.83$ & 221.73 & $9,872.55$ & $3,653.74$ & $7,766.92$ \\
\hline Lagarto & $865,259.49$ & $75,915.91$ & $132,491.10$ & $564,311.29$ & $8,880.80$ & 575.71 & $98,368.70$ & $20,004.34$ & $29,125.96$ \\
\hline Laranjeiras & $1,010,389.03$ & $20,526.21$ & $356,111.18$ & $432,332.01$ & $34,373.41$ & 288.65 & $10,800.85$ & $5,872.64$ & $13,592.12$ \\
\hline Macambira & $43,968.70$ & $4,389.76$ & $3,767.67$ & $33,936.47$ & $2,063.67$ & 165.77 & $7,077.24$ & $1,565.54$ & $5,825.19$ \\
\hline Malhada dos Bois & $30,111.37$ & $1,992.04$ & $2,820.14$ & $23,361.56$ & $3,221.36$ & 158.49 & 564.85 & 881.50 & $5,825.19$ \\
\hline Malhador & $76,136.59$ & $8,303.18$ & $6,268.76$ & $58,225.39$ & $2,127.47$ & 208.32 & $10,358.88$ & $2,727.37$ & $7,766.92$ \\
\hline Maruim & $204,414.35$ & $9,206.07$ & $69,373.11$ & $105,345.00$ & $4,269.24$ & $1,795.58$ & $12,115.18$ & $3,541.01$ & $9,708.65$ \\
\hline Moita Bonita & $71,659.91$ & $9,229.03$ & $5,764.08$ & $53,370.24$ & $2,183.83$ & 266.70 & $14,889.10$ & $1,982.79$ & $7,766.92$ \\
\hline Monte Alegre de Sergipe & $92,774.96$ & $13,314.46$ & $7,220.54$ & $68,158.56$ & $2,168.75$ & 234.18 & $10,929.67$ & $3,631.17$ & $9,708.58$ \\
\hline Muribeca & $58,514.81$ & $5,050.71$ & $11,587.65$ & $38,240.63$ & $2,078.56$ & 211.30 & $1,143.95$ & $1,658.32$ & $5,825.20$ \\
\hline Neopolis & $165,026.63$ & $25,699.78$ & $23,988.11$ & $101,630.91$ & $3,732.10$ & 281.47 & $20,832.66$ & $5,022.69$ & $11,650.56$ \\
\hline Nossa Senhora Aparecida & $80,459.18$ & $9,430.88$ & $15,655.88$ & $46,951.69$ & $2,178.50$ & 149.06 & $9,661.85$ & $2,334.84$ & $5,825.19$ \\
\hline Nossa Senhora da Gloria & $346,380.84$ & $35,796.19$ & $50,491.00$ & $222,824.73$ & $5,132.93$ & 359.15 & $36,433.36$ & $7,911.26$ & $15,533.85$ \\
\hline Nossa Senhora das Dores & $217,584.93$ & $24,063.32$ & $32,003.31$ & $143,613.19$ & $3,210.95$ & 285.52 & $26,935.96$ & $5,727.24$ & $13,592.12$ \\
\hline Nossa Senhora de Lourdes & $42,042.52$ & $6,206.53$ & $3,533.05$ & $30,635.37$ & $2,217.01$ & 162.60 & $6,948.33$ & $1,642.43$ & $5,650.03$ \\
\hline Nossa Senhora do Socorro & $2,049,719.31$ & $5,055.71$ & $299,346.09$ & , 342,467.46 & $24,976.16$ & $2,115.50$ & $25,456.08$ & $29,316.70$ & $63,576.01$ \\
\hline Pacatuba & $111,861.63$ & $19,007.02$ & $21,092.26$ & $66,986.79$ & $5,296.21$ & 537.70 & $10,953.92$ & $4,191.82$ & $7,767.57$ \\
\hline
\end{tabular}




\begin{tabular}{|c|c|c|c|c|c|c|c|c|c|}
\hline \multirow{2}{*}{ MUNICIPALITIES } & \multirow{2}{*}{ GDP } & \multicolumn{3}{|c|}{ VALUE ADDED } & \multirow{2}{*}{$\begin{array}{c}\text { ICMS } \\
\text { Transfers }\end{array}$} & \multirow{2}{*}{ Royalties } & \multirow{2}{*}{$\begin{array}{c}\text { Social } \\
\text { Security }\end{array}$} & \multirow{2}{*}{ PBF } & \multirow{2}{*}{ FPM } \\
\hline & & Agriculture & Industry & Services & & & & & \\
\hline Pedra Mole & $21,850.5$ & $2,379.44$ & $1,745.22$ & $17,135.45$ & $1,947.19$ & 162.37 & $2,367.49$ & 724.43 & $5,825.19$ \\
\hline Pedrinhas & $50,293.34$ & $2,190.64$ & $4,681.09$ & $41,616.77$ & $2,125.41$ & 228.21 & $1,218.25$ & $2,311.25$ & $6,769.81$ \\
\hline Pinhão & $41,139.35$ & $4,276.30$ & $3,549.92$ & $31,429.81$ & $2,026.16$ & 209.43 & $1,136.81$ & $1,386.87$ & $5,825.19$ \\
\hline Pirambu & $69,584.61$ & $4,937.92$ & $17,240.59$ & $44,987.55$ & $2,588.48$ & $10,539.31$ & $2,586.42$ & $1,964.25$ & $5,825.19$ \\
\hline Poço Redondo & $187,705.97$ & $28,816.95$ & $15,799.17$ & $134,933.35$ & $2,330.21$ & 317.26 & $18,513.61$ & $9,009.22$ & $15,533.85$ \\
\hline Poço Verde & $133,678.45$ & $7,906.73$ & $11,968.79$ & $106,864.31$ & $2,544.46$ & 247.28 & $27,100.36$ & $6,007.54$ & $11,650.38$ \\
\hline Porto da Folha & $197,471.55$ & $27,796.27$ & $20,113.40$ & $140,642.15$ & $2,533.58$ & 354.06 & $25,029.60$ & $7,619.02$ & $13,592.12$ \\
\hline Propria & $313,990.02$ & $9,777.37$ & $54,292.19$ & $211,298.97$ & $5,876.54$ & 288.69 & $48,381.69$ & $5,909.20$ & $13,592.12$ \\
\hline Riachão do Dantas & $113,901.54$ & $16,585.55$ & $9,172.56$ & $84,989.43$ & $2,076.19$ & 244.55 & $18,449.67$ & $5,488.38$ & $11,650.38$ \\
\hline Riachuelo & $148,608.45$ & $7,371.05$ & 75836.13 & $53,393.03$ & $4,321.38$ & $2,138.79$ & $3,652.54$ & $2,246.12$ & $5,825.19$ \\
\hline Ribeiropólis & $152,027.07$ & $9,799.70$ & $27,557.30$ & $100,273.07$ & $3,608.18$ & 241.03 & $22,663.18$ & $3,571.66$ & $11,650.38$ \\
\hline Rosário do Catete & $408,965.32$ & $10,142.27$ & $246,908.26$ & $98,163.84$ & $16,280.17$ & $8,821.06$ & $3,843.56$ & $2,087.73$ & $5,825.19$ \\
\hline Salgado & $118,824.98$ & $10,387.37$ & $12,640.94$ & $90,315.93$ & $2,400.54$ & 250.62 & $17,147.07$ & $4,194.78$ & $11,650.38$ \\
\hline Santa Luzia do Itanhy & $101,227.62$ & $20,566.88$ & $7,343.96$ & $69,497.40$ & $2,057.60$ & 150.55 & $1,499.30$ & $4,293.27$ & $8,022.30$ \\
\hline Santa Rosa de Lima & $26,201.71$ & $4,105.95$ & $2,130.72$ & $19,212.05$ & $1,986.24$ & 227.26 & 630.07 & $1,046.77$ & $5,825.19$ \\
\hline Santana do São Francisco & $41,939.35$ & $4,615.28$ & $3,994.9$ & $32,192.02$ & ND & ND & $3,272.02$ & $2,031.34$ & ND \\
\hline Santo Amaro das Brotas & $107,527.49$ & $9,066.40$ & $39,899.73$ & $54,946.39$ & $2,440.01$ & $2,089.20$ & $8,733.12$ & $2,641.98$ & $7,766.92$ \\
\hline São Cristovão & $590,068.92$ & $26,006.99$ & $118,211.42$ & $400,880.84$ & $7,474.95$ & $1,815.91$ & $24,336.14$ & $14,469.67$ & $25,242.50$ \\
\hline São Domingos & $66,069.67$ & $4,517.03$ & $9,245.5$ & $48,444.25$ & $2,448.42$ & 294.71 & $7,414.13$ & $2,548.78$ & $7,766.92$ \\
\hline São Francisco & $23,585.72$ & $2,525.37$ & $1,930.5$ & $18,274.45$ & $1,954.49$ & 123.35 & 548.61 & 807.89 & $5,825.19$ \\
\hline São Miguel do Aleixo & $27,030.73$ & $3,877.17$ & $2,129.61$ & $20,037.06$ & $1,950.13$ & 144.06 & 431.55 & $1,083.80$ & $5,825.19$ \\
\hline Simão Dias & $374,946.44$ & $66,032.72$ & $49,477.23$ & $223,864.20$ & $5,360.54$ & 378.13 & $45,012.78$ & $9,741.32$ & $17,475.58$ \\
\hline Siriri & $162,853.11$ & $10,212.96$ & $105,532.02$ & $42,403.57$ & $3,217.80$ & $3,900.59$ & $4,381.74$ & $2,102.58$ & $5,825.19$ \\
\hline Telha & $21,369.7$ & $2,502.21$ & $2,109.84$ & $16,131.38$ & $1,985.34$ & 144.15 & 541.51 & 792.66 & $5,825.19$ \\
\hline Tobias Barreto & $337,076.51$ & $17,034.71$ & $40,857.76$ & $251,689.94$ & $4,297.87$ & 387.08 & $53,006.31$ & $11,010.29$ & $19,417.31$ \\
\hline Tomar do Geru & $77,866.56$ & $7,136.25$ & $7,124.65$ & $60,655.09$ & $2,147.96$ & 184.53 & $11,681.57$ & $3,836.36$ & $7,766.92$ \\
\hline Umbaúba & $167,750.04$ & $6,523.81$ & $16,707.06$ & $130,445.79$ & $3,023.30$ & 253.78 & $15,322.87$ & $5,249.01$ & $11,650.38$ \\
\hline MEAN & $370,975.89$ & $13,781.63$ & $94,456.19$ & $218,850.84$ & $7,680.18$ & $2,459.45$ & $24,497.60$ & $5,239.67$ & $13,451.71$ \\
\hline Standard Error & $1,160,862.70$ & $13,411.93$ & $235,373.46$ & $802,005.46$ & $20,095.16$ & $6,877.06$ & $82,000.73$ & $7,117.01$ & $23,016.94$ \\
\hline
\end{tabular}

Source: www.mds.gov.br, www.seplag.se.gov.br and www.stn.fazenda.gov.br (accessed 06.10.2013)

Table 4: Results of Estimations

\begin{tabular}{l|c|c}
\hline & $\mathrm{FE}$ & $\mathrm{RE}$ \\
\hline r2 within & 0.5230 & 0.5061 \\
\hline between & 0.9635 & 0.9808 \\
\hline overall & 0.9618 & 0.9794 \\
\hline Constant & 0.00005 & -0.00001 \\
\hline VAAgric. & {$[0.569]$} & {$[0.999]$} \\
\hline & $0.15773^{*} *$ & 0.00535 \\
\hline VAInd & {$[0.021]$} & {$[0.454]$} \\
\hline Royalties & $0.28564 *$ & $0.29471^{*}$ \\
\hline & {$[0.000]$} & {$[0.000]$} \\
\hline Social Security & $0.29859^{* *}$ & $0.66945^{*}$ \\
\hline
\end{tabular}

Table 4: Results of Estimations conclusão

\begin{tabular}{l|c|c}
\hline & FE & RE \\
\hline & {$[0.024]$} & {$[0.000]$} \\
\hline PBF & 0.08645 & 0.09297 \\
\hline & {$[0.266]$} & {$[0.228]$} \\
\hline F & 33.53 & \\
\hline & {$[0.000]$} & \\
\hline $\mathrm{c}^{2}$ & & $3,841.48$ \\
\hline & & {$[0.000]$} \\
\hline
\end{tabular}

* significant $1 \%$ error

** significant $5 \%$ error p-value in brackets 
Observing the table, it can be seen that the fixed effects model explained $52 \%$ of variance of GDP in the period. Note that only the coefficients of value added of agriculture, industry and transfers of social security benefits are statistically significant and have the expected signs. Bolsa Família allowances, however, do not seem to contribute to GDP of the state's municipalities, differently from Jorge and Graça (2012), who found a significant and positive effect of PBF for the cities of Baixo São Francisco Sergipano Region, characterized by the small size and low dynamism of their economies.

On the other hand the random effects model has a coefficient of determination ( $\mathrm{r} 2$ overall) of about $98 \%$, but only the value added of industry and social security disbursements are statistically significant and have the expected signs. Again, the payments of Bolsa Família do not seem to contribute to GDP growth of the state's municipalities.

Despite the PBF disbursements have been shown to be not statistically significant in the two estimates, the results differ and thus is necessary to perform a test to identify the most appropriate technique. As we used the robust variance matrix, however, the Hausman test cannot be applied. In this case, it applies the Sargan-Hansen test, whose result of 59.218 ( $p$-value $=0.000)$ indicates the fixed effects model as the most appropriate ${ }^{6}$.

Thus, the value added of agriculture and industry, as well as of social security transfers, explain about $52 \%$ of GDP variance in the municipalities, especially the last two, whose $\beta$ appears to be more significant. Bolsa Família allowances, however, seem not statistically affect the municipal GDP, in spite of representing a significant percentage of the economy of smaller localities.

\section{MAIN CONCLUSIONS}

This article started from the assumption that the PBF has not only micro but also macroeconomic impacts and the lower the economic strength of a municipality, the most important should be such

\footnotetext{
${ }^{6}$ When the Hausman test generates a negative signal or a non-positive definite matrix, Prof. Mark Schaffer of Heriott-Watt University (Edinburgh) suggests replacing it by the Sargan-Hansen test, which produces a necessarily positive result whose interpretation is similar to the Hausman test. (www.statalist. com.it/).
}

impacts in relative terms. In this sense, the study aimed to observe the impact of direct income PBF transfers on GDP of municipalities in the state of Sergipe between 2004 and 2012.

The state of Sergipe was chosen because it is made up of small towns and reduced economic dimension, where the transfer of funds of the Union and states often have significant weight in the composition of their tax revenues. In addition all cities of Sergipe receive oil royalties.

Then a simple model was built seeking to observe the effect of four transfer revenues on the municipal GDP: FPM, royalties, social security disbursements and PBF allowances. To capture the dynamics of the local economy the value added of the three sectors of the economy and the value of the ICMS transfers were included.

The fixed effects model explained $52 \%$ of variance of GDP in the period. It was verified that the coefficients of the value added of agriculture, industry and social security benefits are statistically significant, but disbursements of the Bolsa Familia program do not appear to have statistically contributed to GDP of municipalities in Sergipe.

It is important to mention that the results should not be extrapolated to other states or regions, due to the particularities of the municipalities of Sergipe captured by the fixed effects. Besides that, our results should be viewed with some caution due to the possibility of endogeneity.

Obviously, it is a simple model that can be enhanced with the inclusion of other relevant variables such as the Municipal Human Development Index (IDH-M) or some institutional information from municipalities. Another suggestion is to use instrumental variables techniques to address a possible endogeneity problem. Thus, the improvement and extension of this work could indicate fruitful paths for future research.

\section{REFERENCES}

ANDRADE, M. V.; CHEIN, F.; SOUZA, L. R. e PUIGJUNOY, J. Income Transfer Policies and the Impacts on the Immunization of Children: the Bolsa Familia Program. Cadernos de Saúde Pública, 28, 7, 2012, p. 1347-1358

BECKER, G. Human Capital. 2a . ed. New York: National Bureau of Economic Research, 1975. 
BRASIL. III - Igualdade de Direitos e Oportunidades. Mensagem ao Congresso Nacional. Brasília: Ministério do Desenvolvimento Social e Combate à Fome (MDS), 2011.

CAMPELO, T. e NERI, M. (org). O Programa Bolsa Família: uma década de inclusão e cidadania. Brasília: IPEA, 2013.

FAGNANI, E. Piso de proteção Social: o debate internacional e a experiência brasileira. Campinas: Instituto de Economia UNICAMP, Texto para Discussão n. 203, 2012.

GOMES, G. M. A economia sem produção do semi-árido nordestino. In J. P. R. Velloso, (coord.) Brasil 500 anos: futuro, presente e passado. Rio de Janeiro: José Olympio, 2000.

INSTITUTO BRASILEIRO DE GEOGRAFIA E ESTATÍSTICA (IBGE). Censo Demográfico 2010. Rio de Janeiro: IBGE, 2011.

JORGE, M. A. Economia do Trabalho: Diferenciais compensatórios de salário e taxas de homicídio no Brasil. São Cristóvão: EDUFS, 2011.

JORGE, M. A.; GRACA, S. M. O Impacto do Programa Bolsa Família no PIB dos Municípios da Região do Baixo São Francisco Sergipano (2008-2011). In: 10. Congresso Brasileiro de Sistemas. Ribeirão Preto/SP. Anais..., 2014.

MARQUES, R. M. Política de transferência de renda no Brasil e Argentina. Revista de Economia Política, 33, 2, 298314, 2013.

MINISTÉRIO DO DESENVOLVIMENTO SOCIAL E DO COMBATE À FOME. http://www.mds.gov.br/bolsafamilia. [Acessed 01.08.2013].

OLIVEIRA, A. H. C. e SOUSA, J. An Evaluation of the Bolsa Família Program in Brazil: Expenditures, education and labor outcomes. Paper presented at Population Association of America 2009 Annual Meeting, Detroit. Annals..., 2009. http://paa2009.princeton.edu/abstracts/90741. [Acessed 07.06.2013].

PROGRAMA DAS NAÇÕES UNIDAS PARA O DESENVOLVIMENTO (PNUD-Brasil) Atlas do Desenvolvimento Humano. Brasília: PNUD; IPEA, 2013.

RUSSEL, T. B. Reducing Poverty Intensity: what alternative poverty measures reveal about the impact of Brazil's Bolsa Familia. Chapel Hill: Chapel Hill University of North Carolina, 2013.

SERGIPE. Produto Interno Bruto dos Municípios 20062010. Aracaju: Secretaria de Estado do Planejamento, Orçamento e Gestão (SEPLAG), v. 7, 2012.

SILVA, P. O ICMS Como Reflexo do Desenvolvimento Econômico dos Municípios do Estado de Sergipe. Dissertação (Mestrado em Desenvolvimento Regional e Gestão de Empreendimentos Locais). São Cristóvão, Universidade Federal de Sergipe, 2013.
SOARES, F. V.; SOARES, S.; MEDEIROS, M. E OSÓRIO, R. G. Programas de Transferência de Renda no Brasil: Impactos sobre a desigualdade. In XXXIVo. Encontro Nacional da ANPEC, Salvador, BA, Anais... 2006.

SOARES, F. V.; RIBAS, R. F. E OSÓRIO, R. G. Evaluating the Impact of Brazil's Bolsa Família: Cash transfer programs in comparative perspective. Latin American Research Review, 45, 2, 2010, p. 173-190.

TEIXEIRA, O. A.; MELO, R. O. L. e FRANÇA, V. L. A. Construindo um Novo Planejamento Regional Sergipano: os territórios de identidade. In: D. L. Hansen; M. J. N. Soares; R. R. Souza \& R. M. Souza (org). Questão Ambiental e Desenvolvimento Econômico: contribuições teóricas e desafios contemporâneos. São Cristóvão: EDUFS; Aracaju: Fundação Oviêdo Teixeira, 2010.

WOOLDRIDGE, J. Econometric analysis of cross section and panel data. Cambridge: MIT Press, 2002. 